\title{
Synergistic Effects of Physicochemical Parameters on Bio-Fabrication of Mint Silver Nanoparticles: Structural Evaluation and Action Against HCTII6 Colon Cancer Cells
}

This article was published in the following Dove Press journal:

International Journal of Nanomedicine

\author{
Bilal Javed (iD) ${ }^{1,2}$ \\ Zia-ur-Rehman Mashwani (iD) ${ }^{2}$ \\ 'Roy \& Diana Vagelos Laboratories, \\ Department of Chemistry, University of \\ Pennsylvania, Philadelphia, PA 19104- \\ 6323, USA; '2Department of Botany, \\ PMAS Arid Agriculture University, \\ Rawalpindi, Punjab 46300, Pakistan
}

Background: Physicochemical parameters such as temperature, $\mathrm{pH}$, the concentration of the $\mathrm{AgNO}_{3}$ and ratio of reactants act synergistically to influence the reaction kinetics, molecular mechanics, enzymatic catalysis and protein conformations that aid to affect the size, shape and biochemical corona of nanoparticles. The present study was performed to investigate the influence of reaction parameters on the bio-fabrication of silver nanoparticles (AgNPs) by using Mentha arvensis and to determine their potential to control the proliferation of colon cancer cells'.

Methods: Plant-mediated method was used for the bio-fabrication and stabilization of AgNPs. Reaction parameters were arranged, and surface plasmon resonance (SPR) bands of AgNPs were collected by using a UV-Visible spectrophotometer. NPs were characterized structurally and optically by using SEM, AFM, EDX and DLS techniques. AgNPs and plant aqueous extract were tested against HCT116 colon cancer cells by using SRB assay, Annexin $\mathrm{V}$ assay and cell cycle analysis.

Results: Spectrophotometric comparison of various reaction conditions manifested that 5 $\mathrm{mM}$ of $\mathrm{AgNO}_{3}, 60^{\circ} \mathrm{C}$ in an acidic $\mathrm{pH}$ and a mixing ratio of $1: 9$ of plant extract and $\mathrm{AgNO}_{3}$, respectively, are the optimized conditions for AgNP synthesis. Structural evaluation by SEM, AFM and particle size analysis confirmed that the NPs are $<100 \mathrm{~nm}$ and are anisotropic, spherical, triangular and moderately dispersed in the colloidal mixture. SRB assay expressed biomass-stabilized AgNPs as effective cytotoxic particles against HCT116 colon cancer cells, and the $\mathrm{IC}_{50}$ was measured at $1.7 \mu \mathrm{g} / \mathrm{mL}$. Annexin $\mathrm{V}$ apoptosis assay further confirmed that the AgNPs induce apoptosis in a dose-dependent manner. Experimental evidence manifested that the AgNPs arrest cell cycle and expressed entrapment of a greater number of cells in the Sub-G1 phase, further verifying the anticancer abilities of AgNPs.

Conclusion: These findings explain the synergistic effects of physicochemical parameters to optimize the phytosynthesis of biocompatible AgNPs to overcome the limitations of conventional chemotherapeutic treatments of colon cancer cells.

Keywords: anticancer, cell cycle analysis, colorectal cancer, green synthesis, Mentha arvensis, reaction dynamics

\section{Introduction}

Plant body act as a repository of diverse secondary metabolites that are not only responsible for various environmental, social and defensive responses of plants but also provide many benefits to humans. ${ }^{1}$ Plants have natural mechanisms to entrap
Correspondence: Bilal Javed
Zia-ur-Rehman Mashwani

Department of Botany, PMAS Arid Agriculture University, Rawalpindi, Punjab 46300, Pakistan

Email javedbilal87@gmail.com;

zia.botany@gmail.com 
metallic constituents found in their vicinity by their absorption from the soil solution and their transport to different plant organs to convert them into nanometals that later assimilate into their bodies and prevent plants from the toxic effects of excessive metals into their habitat. ${ }^{2,3}$ The top-bottom approach to carve the bulk materials into their nano-forms by using the reducing and stabilizing abilities of plant secondary metabolites depends greatly on reaction conditions that can be harnessed by physicochemical parameters and influence the final size, shape, and capping of nanomaterials. ${ }^{4-6}$

Physicochemical parameters provide a toolbox to carve nanoparticles and have different effects. Temperature plays a vital role by not only providing the activation energy that is usually required for the inception of a chemical reaction but also favors by increasing the molecular collision that enhances the possibility of the reactants to collide and convert into their resultant product. Different $\mathrm{pH}$ ranges have different influences on the reaction kinetics and molecular dynamics. $\mathrm{pH}$ contributes greatly to increase or decrease the number of $\mathrm{H}^{+}$ions in the reaction mixture. ${ }^{7}$ Lower the $\mathrm{pH}$ value results in increasing the concentration of $\mathrm{H}^{+}$. $\mathrm{pH}$ does not directly affect the conformational changes of proteins and enzymes but the change in the concentration of $\mathrm{H}^{+}$ions can shape and alter the electronegative properties of the substrate that can affect their binding with the enzymatic active site. ${ }^{2,8,9}$ The ratio of reactants, their proportion and conjunction with catalyst act in a synergistic fashion along with temperature and $\mathrm{pH}$. Modulation of physicochemical switches have effects on the morphological and biochemical basis of nanostructures that contribute toward their biocompatibility and make them suitable to treat various diseases. ${ }^{10,11}$

Cancer is reported as a leading cause of death with around more than 10 million cases every year and is caused by clonally selected mutations in key tumorsuppressor genes and oncogenes. ${ }^{12}$ Conventional treatment of cancer involves the surgical removal of cancer sites, chemotherapeutic and radioactive killing of the cancer cells but these treatments often lead to the deterioration of the patient's body and development of resistance in cancer cells against treatment that negatively affect the treatment success rate. ${ }^{13-15}$ Colorectal cancer is the third most common cancer and makes $10 \%$ of all reported cases worldwide. Conventional oncological medicines against colorectal cancer results in the damage of many healthy cells and vital organs of patients owing to a decrease in quality of life. The route of administration of cancer chemotherapeutics involves the circulation through the bloodstream to the cancer site and does not have any selectivity. Radioactive treatment of colorectal cancer results in extreme diarrhea, abdominal pain, difficulty to urinate and pain during defecation which make routine medicines very unsuitable for patients. Tumor cells have biology different than normal cells such as the rapid proliferation of blood vessels that is called angiogenesis, poor permeability of vessels and lymphatic drainage. This varied behavior of cancer cells from normal cells has used as an opportunity by nanotechnologists to design functional nanodrugs to target cancer cells with utmost selectivity and precision. ${ }^{16-18}$

Plant-mediated green synthesis provides an advantage to synthesize nanoparticles of biocompatible nature without adding additional capping or stabilizing agents. ${ }^{19}$ The plant body has many different functional groups that cap the metallic core of the $\mathrm{Ag}$ and prevent them from agglomeration. ${ }^{20}$ There are many reports available about phytosynthesis of nanoparticles but the detailed studies explaining the role of different physicochemical parameters and their synergic effects on the synthesis of AgNPs are limited. The present study was devised to use Mentha arvensis (mint) from the Lamiaceae family well renowned for the presence of antioxidants, ${ }^{21}$ to tailor AgNPs and study the effects of different reactions conditions on reaction kinetics, molecular mechanics and the yield of nanoparticles. Herein we report the (schematic overview is represented in Scheme 1) synergistic effects of various reaction parameters on bio-fabrication of AgNPs, their detailed structural evaluation and abilities to induce apoptosis and cell cycle suspension.

\section{Materials and Methods}

\section{Processing of Plant Material and Aqueous Extract Preparation}

M. arvensis has purchased from the local farmer's market Sialkot $\left(32.485272^{\circ}\right.$ N $74.543575^{\circ}$ E) Pakistan. Samples were washed, dried to remove the moisture, chopped into small pieces and pulverized in the kitchen grinding machine to make a fine powder. For the preparation of aqueous extracts, 1 to 10 ratio of plant material and distilled water was prepared, respectively, and heated on a hot plate at $45-65{ }^{\circ} \mathrm{C}$ for $10-20 \mathrm{~min}$. After the boiling, the aqueous extract was filtered and used immediately as fresh for the reduction of silver salt. ${ }^{20}$ 


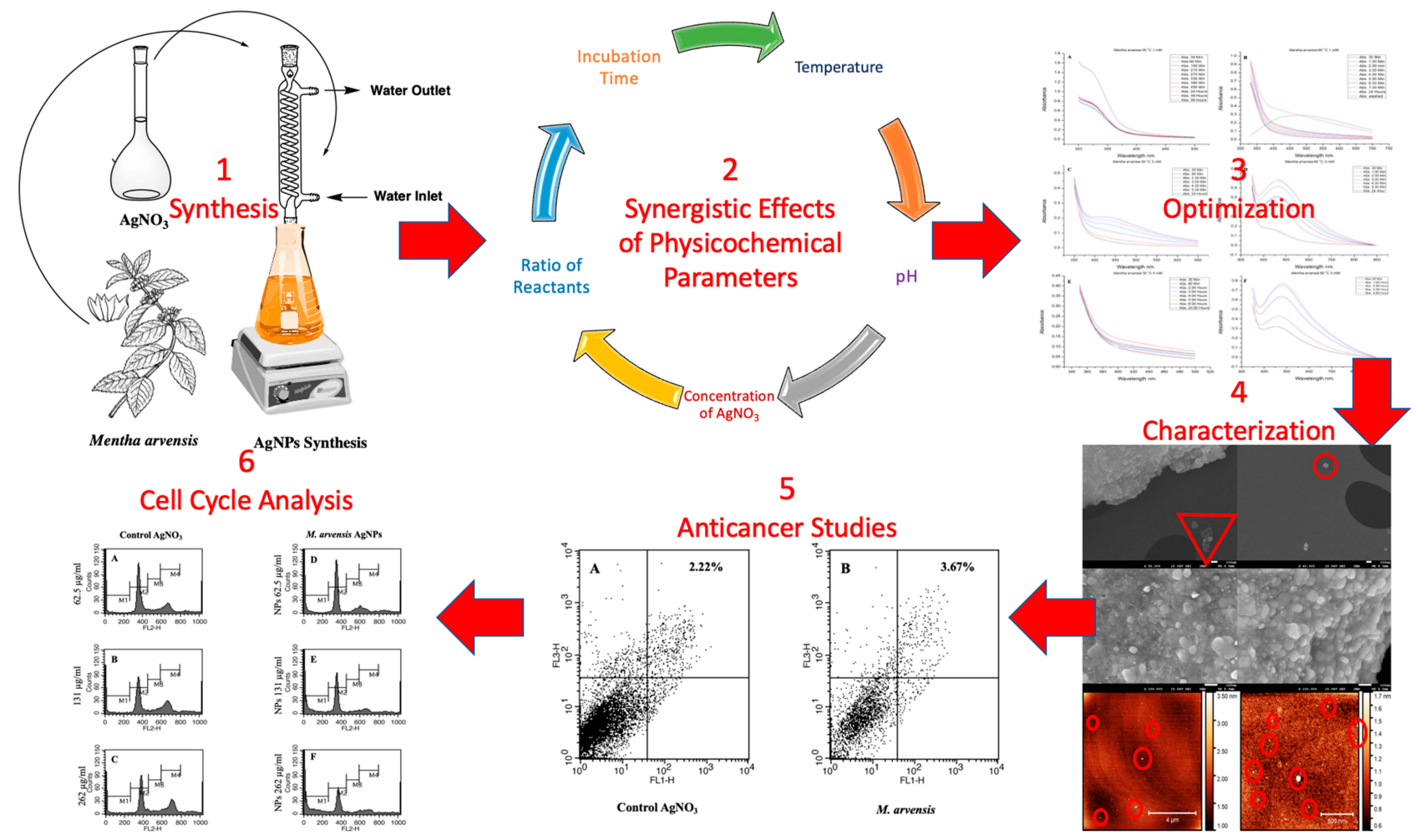

Scheme I Schematic representation of the work layout. Step I and 2 explain the effects of different physicochemical reaction parameters to optimize the synthesis of AgNPs. Step 3 is representing the spectrophotometric results of various reaction conditions. Step 4 is highlighting the characterization of nanostructures. Step 5 and 6 is showing the biological applications of bio-fabricated AgNPs.

Note: Red triangle and circle represent the shape of nanoparticles.

\section{Chemical Reagents}

All chemical reagents purchased for the synthesis and biological applications of silver nanoparticles were of analytical grade and used as received without any further purification.

\section{Phytosynthesis of AgNPs}

Silver nitrate solution of a specific concentration was mixed with freshly prepared plant extract in a ratio of 1 to 9 of plant extract and silver nitrate solution, respectively. The reaction was carried out at a defined $\mathrm{pH}$, temperature and reaction mixture was stirred continuously. An aliquot was taken out from the flask and the absorbance was measured by using crystalline quartz cuvettes with the help of UV-Visible spectrophotometer (Shimadzu 1601, Japan) in the range of 200-900 nm of light wavelength. Absorbance was measured after a specified interval of time to observe the reaction kinetically and to determine the synthesis of AgNPs. After the completion, the reaction was quenched by removing the flask from the hot plate and diluted with a small amount of distilled water. The reaction mixture was centrifuged at
$1000 \times \mathrm{g}$ (Sorvall RT 7 Plus) for 1 hour, thrice to separate the AgNPs from reaction mixture. ${ }^{22}$

\section{Optimization of Physicochemical Parameters for the Synthesis of AgNPs}

The multifactorial experimental design was used to arrange reaction parameters. Physicochemical conditions such as $\mathrm{pH}$, temperature, the concentration of $\mathrm{AgNO}_{3}$, incubation period and plant extract ratio in the reaction mixture were optimized in a way that one parameter was changed while the rest of the parameters were kept constant. Different combinations of reaction conditions were devised to study their synergistic and individual effects. The effects of different reaction conditions on the synthesis of AgNPs were studied by using UV-Visible spectrophotometer. ${ }^{23}$

\section{Determination of Suitable Ratio of Reactants for the Synthesis of AgNPs}

For the determination of the optimum mixing ratio of reactants, a $2 \mathrm{mM}$ solution of $\mathrm{AgNO}_{3}$ was prepared. 100 $\mu \mathrm{L}$ of plant extract was mixed with $900 \mu \mathrm{L}$ of $\mathrm{AgNO}_{3}$ and the concentration of plant extract increased gradually from 
$100 \mu \mathrm{L}$ to $900 \mu \mathrm{L}$ and the concentration of the silver salt solution was decreased subsequently from $900 \mu \mathrm{L}$ to 100 $\mu \mathrm{L}$, to record the effects of different mixing concentrations over the synthesis of AgNPs. Mixtures were incubated in an oven at $60{ }^{\circ} \mathrm{C}$ for 24 hours. At the end of the incubation, period absorbance was recorded in the range of $200-900 \mathrm{~nm}$ of light wavelength. ${ }^{24}$

\section{Morphological and Optical Characterization of AgNPs}

Physical characterization of synthesized silver nanoparticles was performed by using different material characterization techniques to explore their structural morphologies. Nanoparticles synthesis was observed initially by observing a change in the color of the reaction mixture. UVVisible Spectrophotometer (Shimadzu 1601, Japan) was used for the optical characterization and the aliquot of the colloidal AgNPs was observed between 200-900 nm of light wavelength. Scanning Electron Microscope (SEM) JEOL 7500F HRSEM was used to measure the size and shape of nanoparticles by preparation of the samples on copper grids by a drop coating method and observed by using different voltages and laser powers. The elemental composition of AgNPs was determined by Energy Dispersive X-Ray Analysis (EDX) that involves using detectors associated with JEOL 7500F HRSEM. Atomic Force Microscopy (AFM) images were collected on an Agilent 5500 AFM and the sample was placed on a silicon wafer and was prepared on a spin coater (Laurell WS-650Mz-23NPP) machine to spread nanoparticles on a silicon wafer. The hydrodynamic diameter of nanoparticles was measured by preparing colloidal sample solution of nanoparticles into $1 \times$ PBS at $25{ }^{\circ} \mathrm{C}$ by using Dynamic Light Scattering (DLS) machine of Malvern Instruments particle sizer, Zetasizer Nano S, Malvern Instruments, UK and rest of the parameters were adjusted by using automatic machine settings. ${ }^{25-28}$

\section{$\mathrm{IC}_{50}$ Measurement of AgNPs (Sulforhodamine B Assay (SRB))}

For determining the $\mathrm{IC}_{50}$ of nanoparticles, 2000 HCT116 colon cancer cells were seeded in $100 \mu \mathrm{L}$ of DMEM complete medium in a 96 well plate. The next day, cells were treated with different concentrations made by serial dilutions of nanoparticles. After 3 days, cells were fixed by adding $41 \mu \mathrm{L}$ of $10 \%$ TCA directly to the wells. The plate was incubated overnight at $4{ }^{\circ} \mathrm{C}$, washed 4 times with tap water and allowed to dry at $37{ }^{\circ} \mathrm{C}$ for 15 minutes. Cells were stained by adding $100 \mu \mathrm{L}$ of $0.06 \%$ SRB to the wells and incubated for 30 minutes at room temperature. Washing was performed 4 times using $1 \%$ acetic acid in tap water and the plates were allowed to dry for 15 minutes at room temperature. Dye was eluted using 100 $\mu \mathrm{L}$ of $10 \mathrm{mM}$ Tris and incubated at room temperature on a shaker at $300 \mathrm{rpm}$ for 5 minutes. Finally, the absorbance was collected at $490 \mathrm{~nm}$ and $\mathrm{IC}_{50}$ was measured by using GraphPad Prism ${ }^{\circledR}$ software. $^{29}$

\section{Measurement of Apoptotic Colon Cancer Cells Treated with Plant Aqueous Extract and AgNPs (Annexin V Apoptosis Assay)}

Cells were harvested after the incubation period and washed in ice-cold $1 \times$ PBS solution. After that, the cells were resuspended again in ice-cold $1 \times$ PBS and recentrifuged at $300 \times \mathrm{g}$ for $5-10 \mathrm{~min}$ at $4{ }^{\circ} \mathrm{C}$. The supernatant was discarded and the cells were resuspended in $1 \times$ annexin binding buffer (ice cold). The cell density was maintained at $1 \times 10^{6}$ cells $/ \mathrm{mL}$ in $1 \times$ annexin binding buffer. $100 \mu \mathrm{L}$ of cell suspension (resuspended in $1 \times$ Annexin binding buffer) was taken into a new Eppendorf tube and $5 \mu \mathrm{L}$ of Fluorescein isothiocyanate (FITC) or Alexa fluor 488 labeled Annexin V was added to each $100 \mu \mathrm{L}$ cell suspension. Followed by the addition of $1 \mu \mathrm{L}$ of propidium iodide $(100 \mu \mathrm{g} / \mathrm{mL})$ to each $100 \mu \mathrm{L}$ cell suspension. Incubated for $15 \mathrm{~min}$ at room temperature in the dark. At the end of incubation, $400 \mu \mathrm{L}$ of ice-cold annexin binding buffer was added, mixed gently and the samples were incubated on ice and data was acquired on flow cytometer as soon as possible. ${ }^{30}$

\section{Cell Cycle Analysis of AgNPs-Treated HCTII 6 Colon Cancer Cells}

The ability of the Propodium iodide to bind with the DNA stoichiometrically provides an advantage to determine the percentage of the cells into different cell phases that was measured by using cell cycle analysis. ${ }^{31}$ For cell cycle analysis, cells were cultured in a 6-well plate at a density of 1 million. After treatment for 72 hours, cells were collected by trypsinization, washed and fixed with $70 \%$ freshly prepared ethanol for 1 hour on ice. Cells were centrifuged, washed with PBS and resuspended again in $1 \mathrm{~mL}$ PBS supplemented with $5 \mu \mathrm{L}$ of RNAse A and $10 \mu \mathrm{L}$ of Propidium iodide. Incubation was carried out in the dark at $37{ }^{\circ} \mathrm{C}$ for 1 hour and finally, cells were acquired 
by fluorescence-activated cell sorting (FACS) using FL-2 for the detection of Propidium iodide. ${ }^{30}$

\section{Data Analysis}

Graphs were plotted using the Origin Lab $\operatorname{Pro}^{\circledR}$ and Microsoft MS Excel ${ }^{\circledR}$ Program. GraphPad Prism ${ }^{\circledR}$ software was used for the determination of $\mathrm{IC}_{50}$.

\section{Results and Discussion}

\section{Synergistic Effects of Different}

Physicochemical Reaction Conditions on the Synthesis of AgNPs

\section{(Spectrophotometric Analysis)}

Physicochemical parameters provide an only opportunity to act as a toolbox to control the top-bottom carving and fabrication of biogenic materials. $\mathrm{pH}$, temperature, concentration and the proportion of reactants play a vital role to control the chemical kinetics, catalysis and reaction dynamics. ${ }^{7,32,33}$

\section{Effects of Different Concentrations of $\mathrm{AgNO}_{3}$ and Temperature on the Synthesis of AgNPs}

Different physicochemical conditions have different effects on the reaction kinetics, yield, morphological features and on the biochemical attributes of AgNPs. ${ }^{7}$ The concentration of $\mathrm{AgNO}_{3}$ plays a key role to act as a source of the $\mathrm{Ag}^{+}$ions in the reaction mixture. A meager concentration of $\mathrm{Ag}$ may decrease the rate of chemical reaction and excess of $\mathrm{Ag}$ may result in the synthesis of large size nanoparticles or clumps or it may suppress synthesis. ${ }^{34}$ Change in the color of the reaction mixture from clear brown to dark brown was indicated as an initial sign of AgNP synthesis. There was no observable change in the color of the reaction mixture when 1 $\mathrm{mM}$ of $\mathrm{AgNO}_{3}$ was used as reactants (Figure 1A). It can be because of the presence of less $\mathrm{Ag}^{+}$ions in the reaction mixture that does not function to initiate the process of synthesis. Change in the color of the reaction mixture is a response of the interaction of nanoparticles of different sizes and shapes to different electromagnetic light waves. ${ }^{35}$

An increase in the concentration of $\mathrm{AgNO}_{3}$ resulted in increasing the ionic concentration of $\mathrm{Ag}$ that may function to affect the enzymatic conformations and electronegative states of reactants resulted in the change of the color of the reaction mixture (very light brown). Surface plasmon resonance (SPR) band which is a result of the vibration of free electrons of AgNPs in coordination with the metal lattice in resonance and the oscillating electromagnetic field of light waves, was observed ${ }^{36}$ (Figure 1B). Increasing the concentration of the $\mathrm{Ag}$ ions $(5 \mathrm{mM} \mathrm{AgNO})_{3}$ ) resulted in decreasing the synthesis and no SPR band was observed (Figure 1C). It was confirmed that $30{ }^{\circ} \mathrm{C}$ is not a suitable temperature to initiate the redox chemical reactions to reduce the Ag. Even an increase in the concentration of Ag did not affect the reaction kinetics.

Temperature plays a very important role in reaction dynamics by providing activation and kinetic energy. It affects the conformation of many biomolecules and also contributes toward the increase in the kinetic motion of atoms that enhance the process of ionization. ${ }^{8}$ The characteristic SPR band of AgNPs was observed at $3 \mathrm{mM}$ and $5 \mathrm{mM}$ of $\mathrm{AgNO}_{3}$ at $60{ }^{\circ} \mathrm{C}$ (Figure $1 \mathrm{E}$ and $\mathrm{F}$ ), while the reaction proceeded very slow when $1 \mathrm{mM}$ of silver salt was used (Figure 1D). The reaction was completed early $(3 \mathrm{~h})$ when 5 $\mathrm{mM}$ of $\mathrm{AgNO}_{3}$ was used in comparison to $3 \mathrm{mM}(4 \mathrm{~h}$

\& 30 mins) which is represented by the height of the SPR band. According to the Beer Lambert's Law peak height of the SPR band is directly proportional to the concentration of the reacting species. Higher the concentration of the AgNPs higher the SPR band and vice versa. ${ }^{12}$ It was confirmed that the temperature is not only the factor to design the nanoparticles but the concentration of the metallic salt also contributes toward the synthesis along with the incubation period. It was also observed that the SPR band was shifted gradually toward the longer wavelength with an increase in the incubation period (Redshift). According to Mie's scattering theory, ${ }^{37}$ small molecules absorb light at a shorter wavelength while the large molecules absorb light at a longer wavelength. Redshift is expressing an increase in the size of the nanoparticles with an increasing incubation period.

The increasing temperature at $120{ }^{\circ} \mathrm{C}$ was found futile for the synthesis of AgNPs by using M. arvensis aqueous extract (Figure 2A-C). Temperature up to the optimum threshold can denature plant metabolites, alter their functional conformations and breakdown secondary molecules that hinder synthesis.

\section{Effects of Different pH Conditions Along with the Concentrations of $\mathrm{AgNO}_{3}$ on the Synthesis of AgNPs}

$\mathrm{pH}$ plays a very important role in the synthesis of AgNPs by increasing or decreasing the concentration of $\mathrm{H}^{+}$ions that alter the electronegative state of the reactants. ${ }^{11,34}$ 

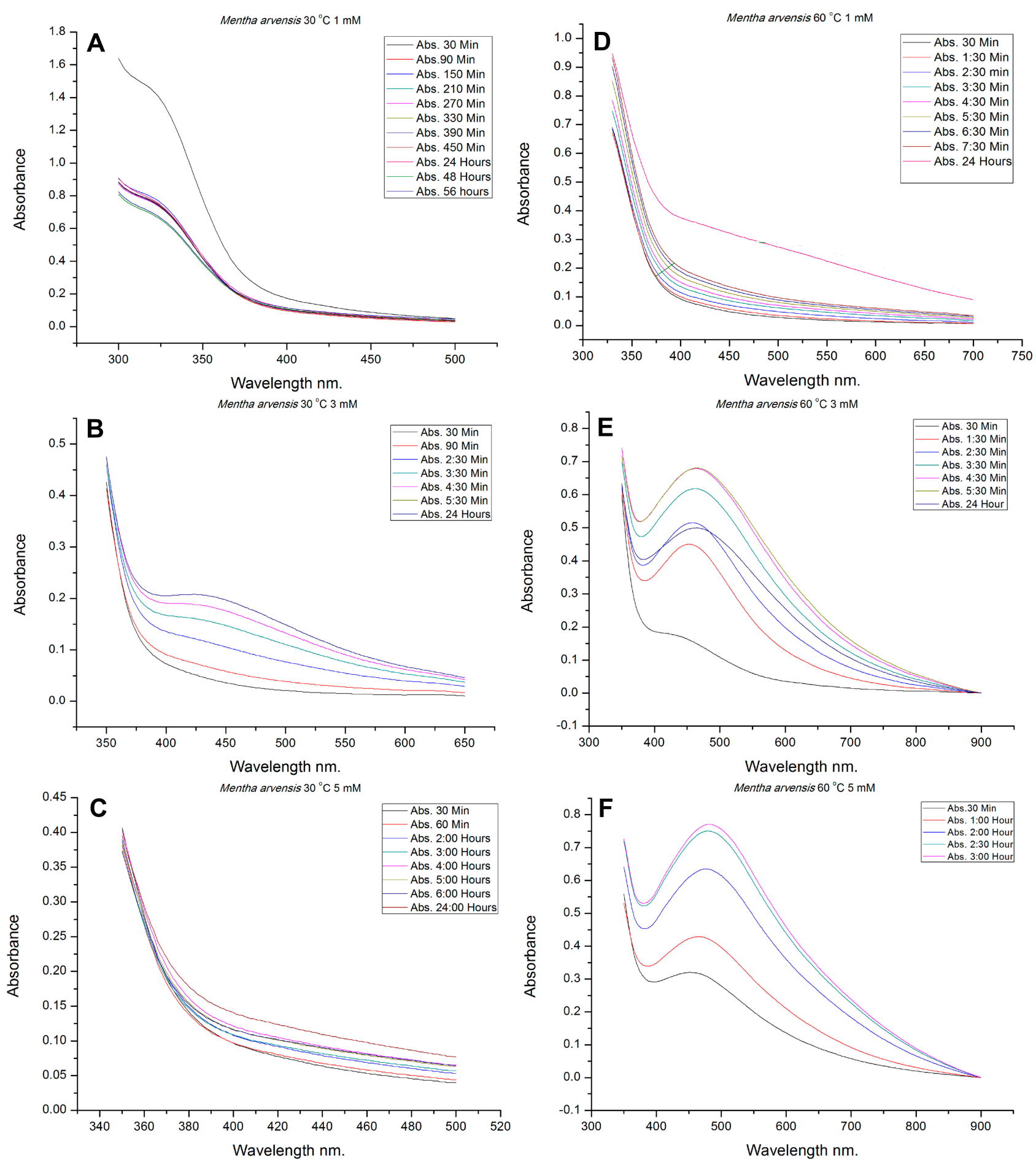

Figure I UV-Visible spectrum representing AgNP synthesis under different physicochemical conditions. (A) Temperature $30^{\circ} \mathrm{C}, \mathrm{I} \mathrm{mM} ;(\mathbf{B})$ temperature $30{ }^{\circ} \mathrm{C}, 3 \mathrm{mM} ;(\mathbf{C})$ temperature $30^{\circ} \mathrm{C}, 5 \mathrm{mM}$; (D) temperature $60^{\circ} \mathrm{C}$, I mM; (E) temperature $60^{\circ} \mathrm{C}, 3 \mathrm{mM}$; (F) temperature $60^{\circ} \mathrm{C}, 5 \mathrm{mM}$.

A set of different $\mathrm{pH}$ conditions acidic, neutral and basic were maintained by adjusting $\mathrm{pH}$ at 5, 7 and 9 respectively. $1 \mathrm{mM}$ of the $\mathrm{AgNO}_{3}$ did not report any change in color of the reaction mixture at acidic and basic $\mathrm{pH}$ (Figure 2D and F) but there was a slight increase in the SPR band height at neutral pH (Figure 2E).
A very broad asymmetrical peak was observed at acidic $\mathrm{pH}$ when $3 \mathrm{mM}$ of $\mathrm{AgNO}_{3}$ was used (Figure 3A). SPR band was also broad at neutral $\mathrm{pH}$ (Figure 3B) but it was very meager at basic $\mathrm{pH}$ (Figure 3C). According to the spectroscopic peak analysis broad peak represents the anisotropic, large size or big clumps of polydisperse nanoparticles. SPR band is a response 

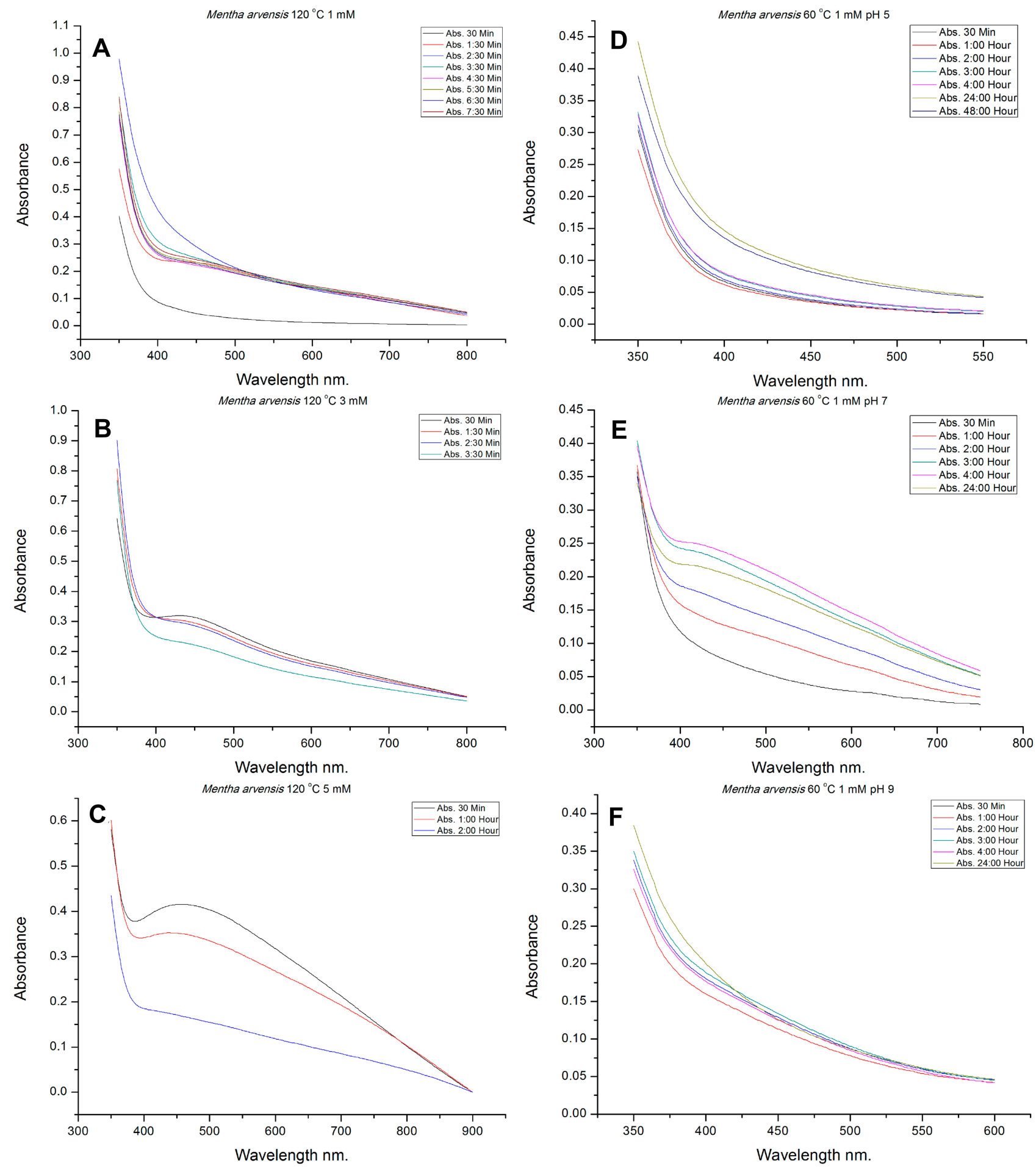

Figure 2 UV-Visible spectrum representing AgNP synthesis under different physicochemical conditions. (A) Temperature $120^{\circ} \mathrm{C}, 1 \mathrm{mM}$; (B) temperature $120{ }^{\circ} \mathrm{C}, 3 \mathrm{mM}$; (C) temperature $120^{\circ} \mathrm{C}, 5 \mathrm{mM}$; (D) temperature $60^{\circ} \mathrm{C}, 1 \mathrm{mM}, \mathrm{pH} \mathrm{5}$; (E) temperature $60^{\circ} \mathrm{C}, 1 \mathrm{mM}, \mathrm{pH} 7 ;(\mathbf{F})$ temperature $60{ }^{\circ} \mathrm{C}, \mathrm{I} \mathrm{mM}, \mathrm{pH} 9$.

of morphology, dielectric environment of the synthesized nanoparticles and their composition influence. ${ }^{12}$

The shape of the SPR band determines the shape of the nanoparticles. Symmetrical and narrow SPR band represents the small, spherical and monodisperse nanoparticles. ${ }^{38}$
A very symmetrical and narrow SPR band was observed at acidic $\mathrm{pH}$ when $5 \mathrm{mM}$ of $\mathrm{AgNO}_{3}$ was used (Figure 3D) and the synthesis of NPs at basic and neutral $\mathrm{pH}$ was very meager (Figure 3E and F). So $5 \mathrm{mM}$ with acidic $\mathrm{pH}$ was selected as the optimum condition for the phytosynthesis of 

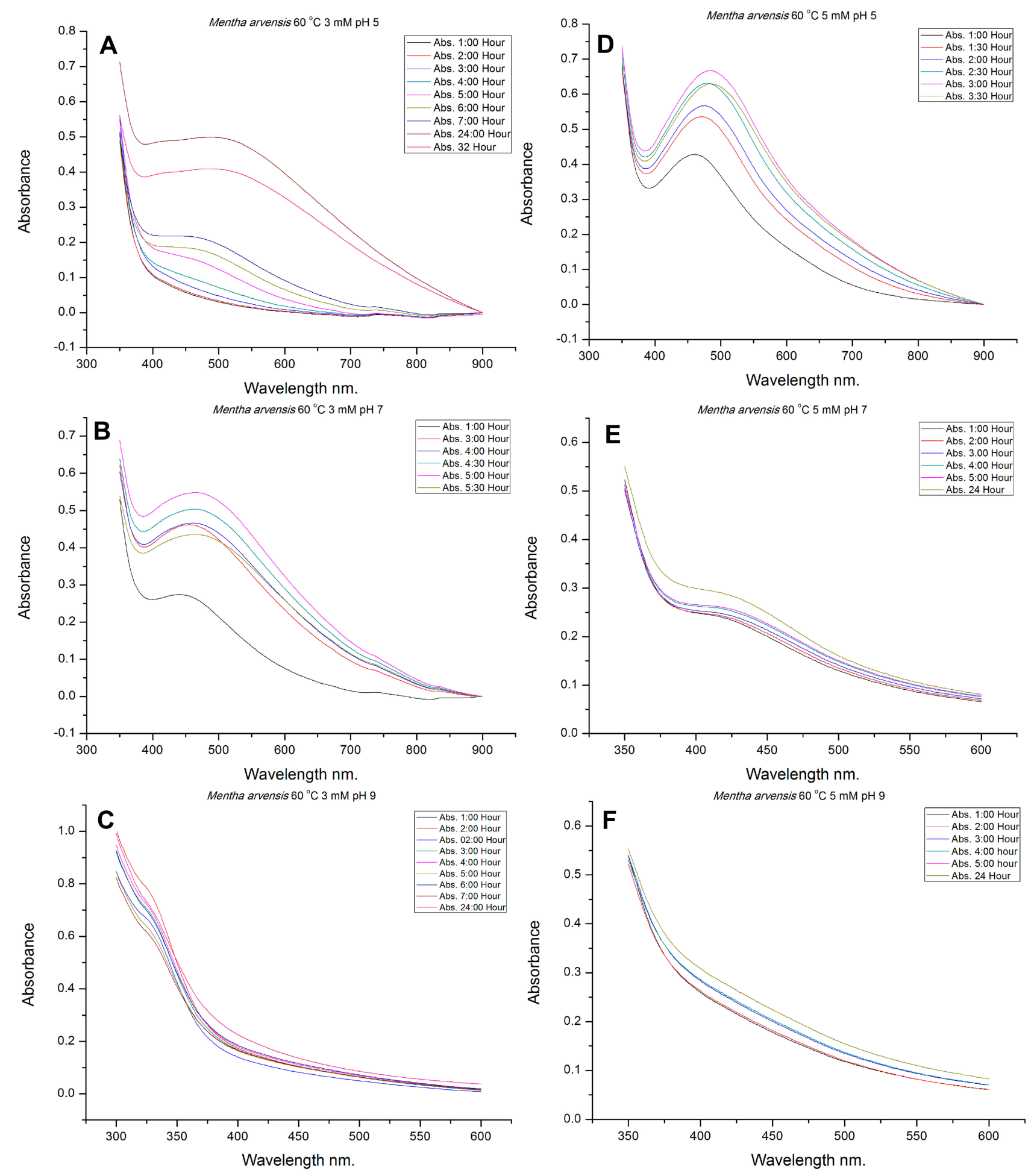

Figure 3 UV-Visible spectrum representing AgNP synthesis under different physicochemical conditions. (A) Temperature $60{ }^{\circ} \mathrm{C}, 3 \mathrm{mM}, \mathrm{pH} 5 ;(\mathbf{B})$ temperature $60{ }^{\circ} \mathrm{C}, 3 \mathrm{mM}$, $\mathrm{pH} \mathrm{7;} \mathrm{(C)} \mathrm{temperature} 60^{\circ} \mathrm{C}, 3 \mathrm{mM}, \mathrm{pH}$ 9; (D) temperature $60^{\circ} \mathrm{C}, 5 \mathrm{mM}, \mathrm{pH} \mathrm{5}$; (E) temperature $60^{\circ} \mathrm{C}, 5 \mathrm{mM}, \mathrm{pH} \mathrm{7;} \mathrm{(F)} \mathrm{temperature} 60{ }^{\circ} \mathrm{C}, 5 \mathrm{mM}, \mathrm{pH} 9$.

AgNPs by using $M$. arvensis aqueous extract as the reducing agent. It can be explained that $\mathrm{pH}$ contributes greatly to increase or decrease the number of $\mathrm{H}^{+}$ions in the reaction mixture that alters the electronegative state of reactants.
Lower the $\mathrm{pH}$ value results in increasing the concentration of $\mathrm{H}^{+}$ions that subsequently increase the collision of the reactants and have a direct influence on the reaction kinetics. $\mathrm{pH}$ does not directly affect the conformational changes of 
proteins and enzymes but the change in the concentration of $\mathrm{H}^{+}$ions can shape and alter the morphological properties of the substrate by changing electronegativity that can affect their binding with the enzymatic active site. ${ }^{39,40}$

\section{Effects of Different Ratios of $\mathrm{AgNO}_{3}$ and Plant Extract on the Synthesis of AgNPs}

Different ratios of the mixture of the plant extract and $\mathrm{AgNO}_{3}$ have different impacts on the synthesis of the AgNPs $^{24}$ (Figure 4A). Analysis of the UV-Vis spectrum manifested that the 1 to 9 ratio of the plant extract and silver nitrate, respectively, as the only proportion to report the synthesis of AgNPs. A specific concentration of Ag ions and plant biomolecules act synergistically to reduce and stabilize the bulk silver. An increase in the concentration of plant extract resulted in an increasing concentration of phytometabolites that suppressed the process of reduction. Ali et $\mathrm{al}^{24}$ studied the effects of different concentrations of plant extracts and $\mathrm{AgNO}_{3}$ that are in favor of our reported results.

\section{Synthesis of AgNPs Under Optimized Physicochemical Conditions}

UV-spectrums were observed critically while the location, absorption unit (a.u.) and the SPR band shift was considered to find out the most suitable conditions for the synthesis of AgNPs (Figure 4B). The peak location of the UV-spectrum depends on particle size, shape, temperature and dielectric constant of the sample medium. ${ }^{8}$ It was found when $5 \mathrm{mM}$ solution of the $\mathrm{AgNO}_{3}$ was mixed with the plant extract in 1 to 9 ratio of the plant extract and silver salt, respectively, and

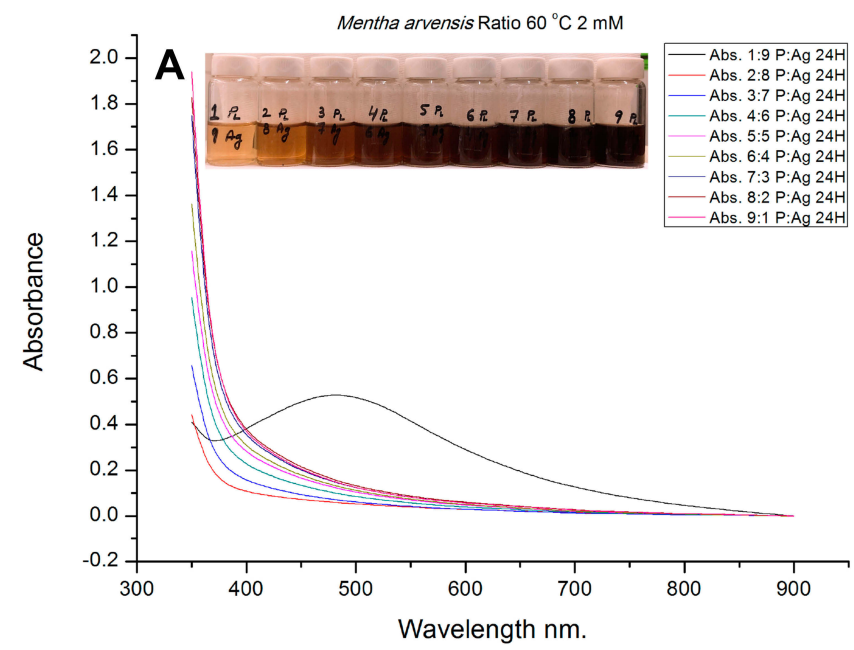

the reaction temperature was maintained at the $60{ }^{\circ} \mathrm{C}$ resulted in the synthesis of AgNPs after the interval of $3 \mathrm{~h}$ and $\mathrm{pH}$ of the reaction mixture measured before synthesis was acidic.

\section{Physical Characterization of AgNPs}

The structural evaluation of AgNPs phytosynthesized and stabilized by the eco-friendly method was performed mainly by using SEM and AFM. SEM micrographs revealed that NPs are anisotropic, nearly spherical, triangular and cubical (Figure 5A and B). The size of the triangular nanoprisms was observed in the range of 90-150 nm (Figure 5A). SEM analysis also reported nanoparticles of various different shapes and sizes (Figure 5C and D). AFM images reported NPs of very small sizes and most of the NPs were found to be in a range of $\sim 7-30 \mathrm{~nm}$ as some large size nanoparticles lost in the air during the process of preparation of the sample. AFM images further confirmed that the NPs are anisotropic and nearly spherical (Figure 6A and B).

The elemental composition of AgNPs was obtained by using EDX analysis (Figure 7). The characteristic peak of Ag was observed at $3 \mathrm{KeV}$ and the intensity of the Ag signal was $\sim 80 \%$. EDX analysis also reported a very small amount of $\mathrm{C}, \mathrm{Cl}, \mathrm{Mg}$, and $\mathrm{Si}$ which maybe because of the stabilization of AgNPs with phytometabolites while the presence of $\mathrm{Cu}$ is maybe because of the involvement of the signals from the copper grid. Figure 7, inset represents the percentage of different elements present in the AgNPs colloidal solution. Some previous studies determined the phytochemical composition of $M$. arvensis and they showed the presence of Chlorinecontaining sesquiterpenes and monoterpene which may be responsible for the presence of $\mathrm{Cl}$ containing $\mathrm{AgNP} .^{41,42}$

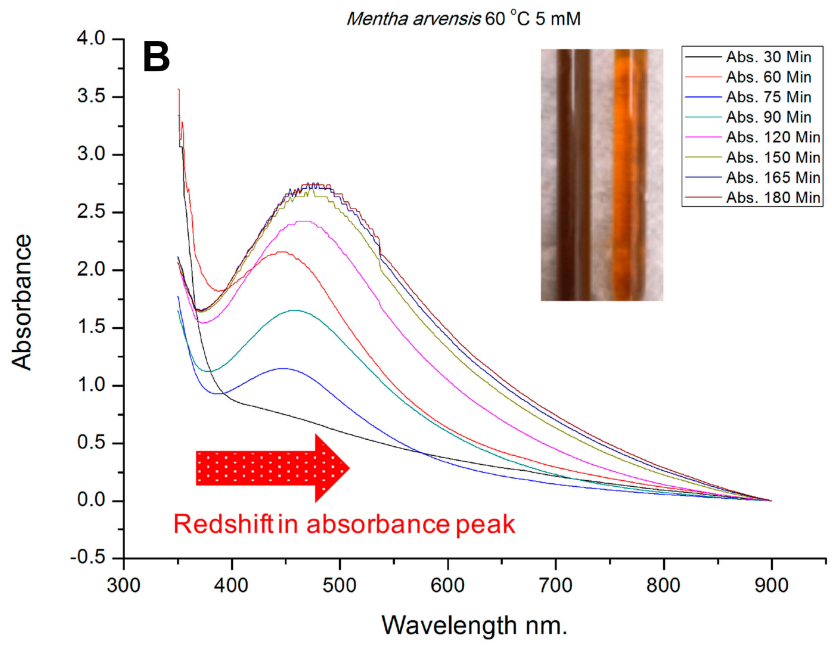

Figure 4 (A) UV-Visible spectrum representing the effects of different ratios of reactants on AgNP synthesis; (B) synthesis under optimized physicochemical conditions. Notes: Red arrow shows redshift in absorbance peak. An increase in the incubation period resulted in increasing the absorbance at a higher wavelength of light. 


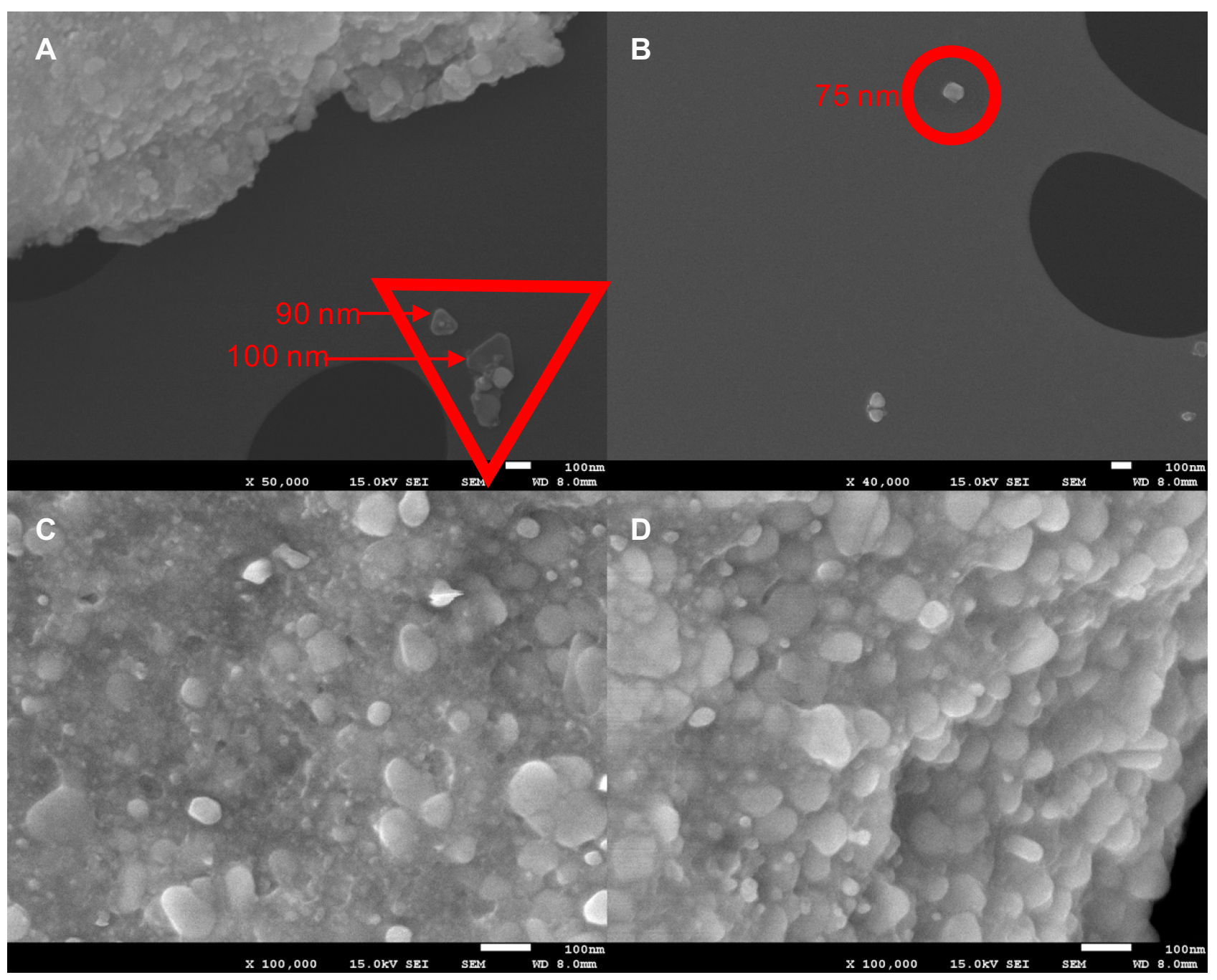

Figure 5 SEM images of AgNPs. (A) Red triangle highlights nanoprisms; (B) red circle represents a small spherical nanoparticle; (C and D) NPs of different shapes and sizes.
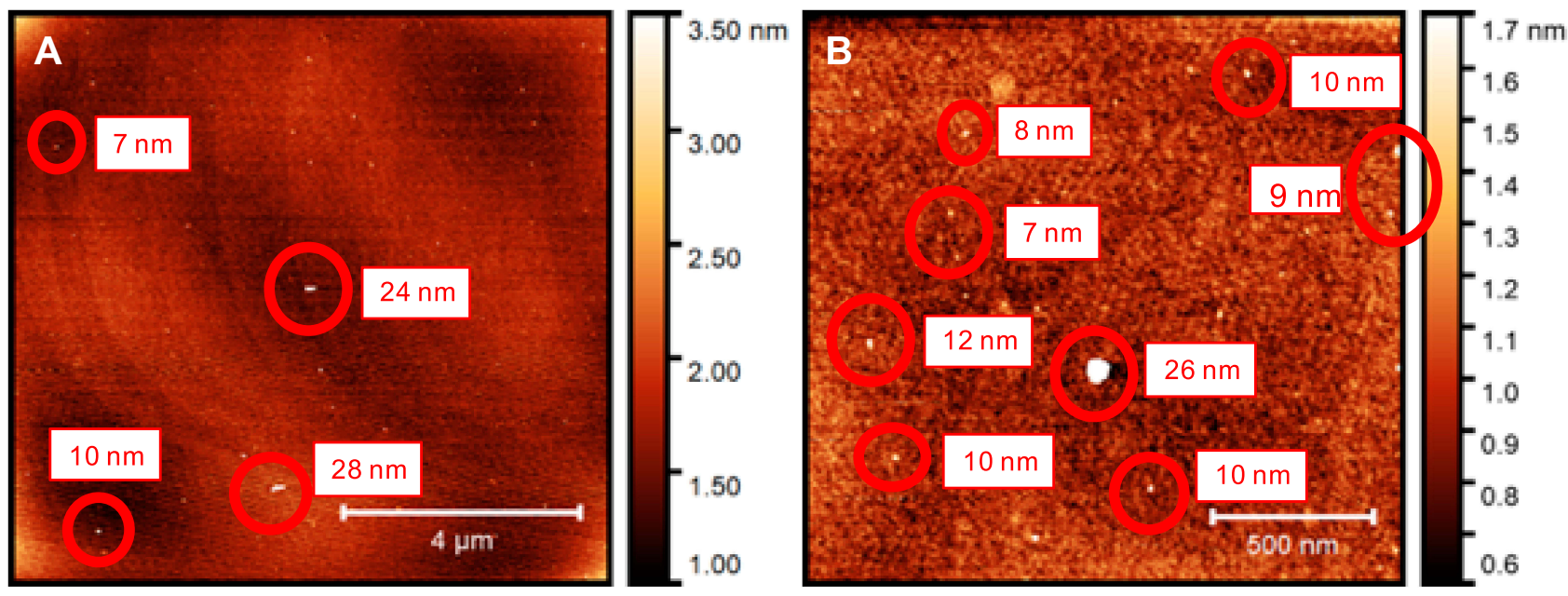

Figure 6 AFM images of AgNPs. (A and B) Red circles highlight the NPs of different shapes and sizes. 


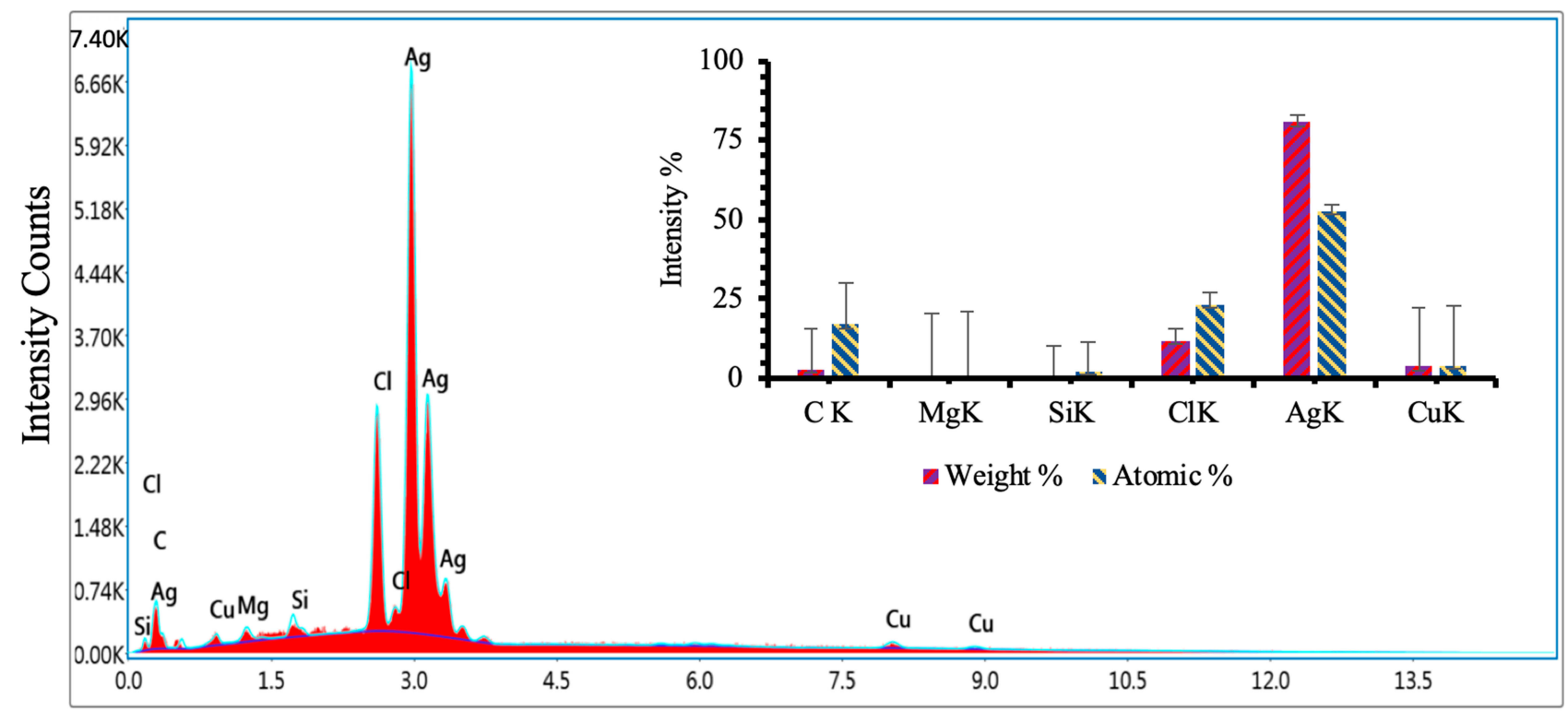

Energy $\mathrm{KeV}$

Figure 7 Energy dispersive X-ray analysis to represent the elemental composition of colloidal AgNPs. (inset: Bar chart shows the percentage intensity of different elements).

Size Distribution by Intensity

PDI: 0.209

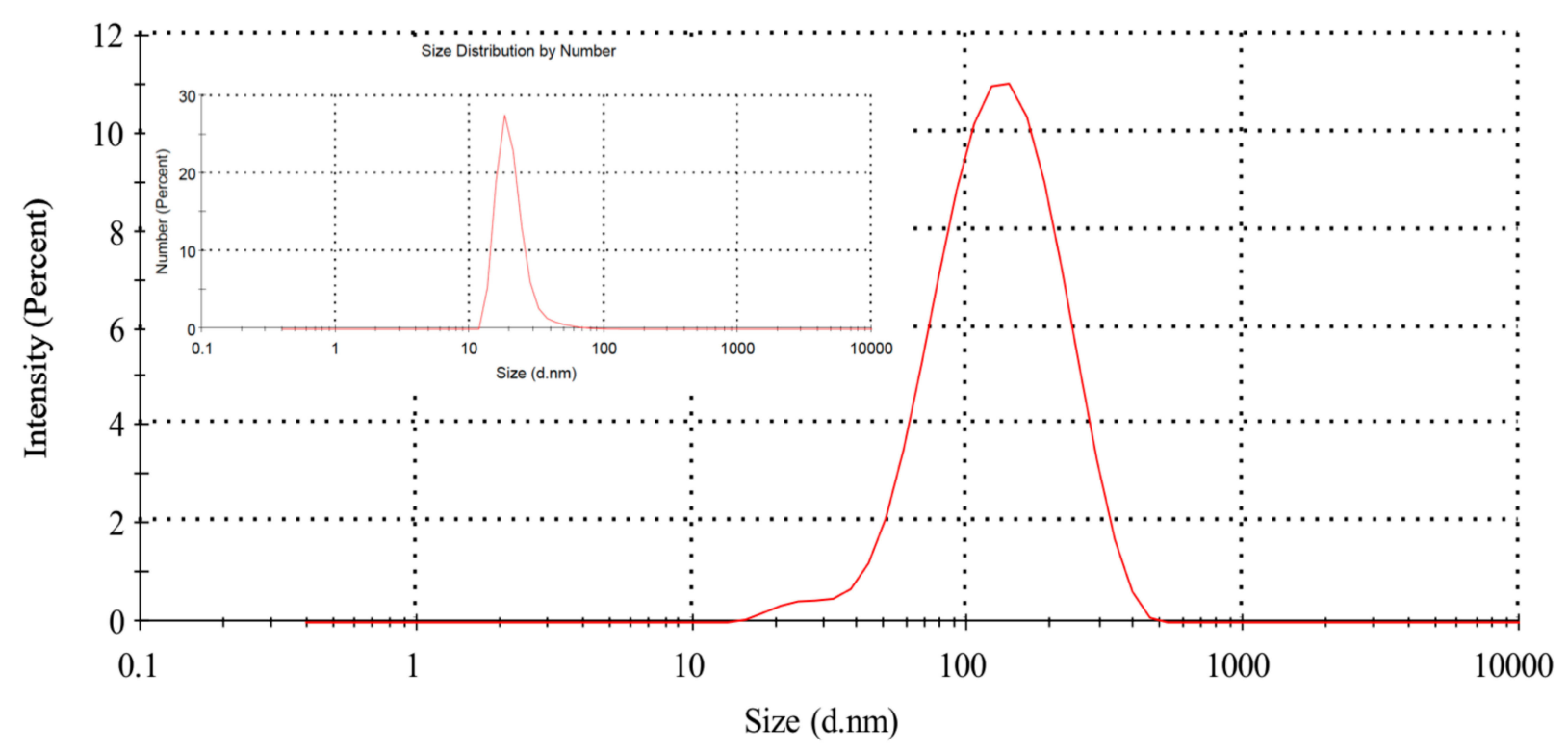

Record 11: MA2

Figure 8 Particle size analysis of biosynthesized AgNPs by using a dynamic light scattering technique. Hydrodynamic diameter of AgNPs was measured between $\sim 17$ and 400 $\mathrm{nm}$, while the average size of most of the nanoparticles was reported 12-40 nm (inset represents particle size distribution of AgNPs by number). 


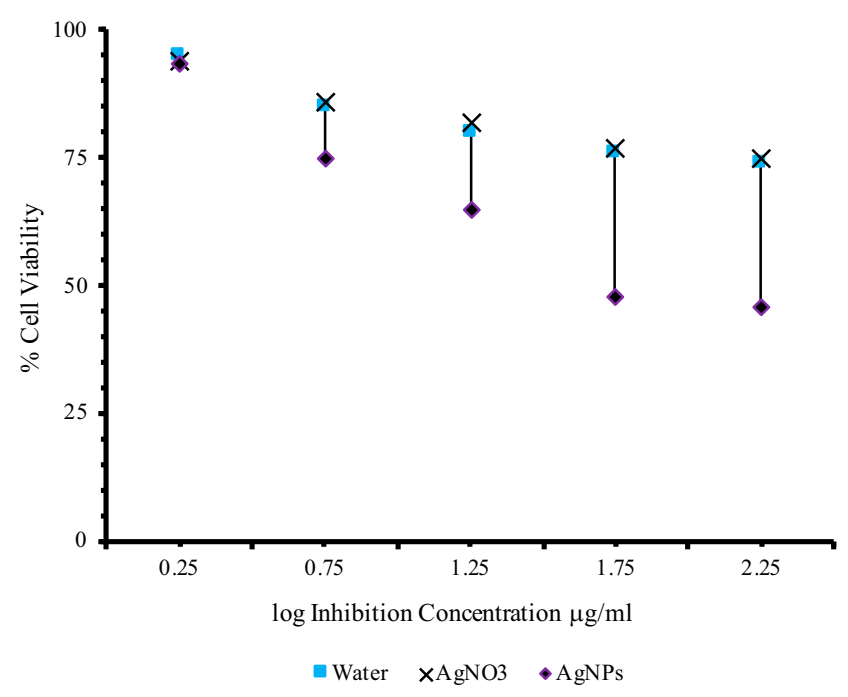

Figure $9 \mathrm{IC}_{50}$ measurement of biosynthesized AgNPs against HCTII6 colon cancer cells. Water was used as negative control, while $\mathrm{AgNO}_{3}$ was used as a positive control.

\section{Particles Size Analysis of AgNPs}

The hydrodynamic particle size distribution of AgNPs in Brownian motion was measured by using a dynamic light scattering technique. The sample was prepared into a $1 \times$ PBS solution to screen the effects of the charge on the surface of nanoparticles. Opposite charge ions from buffer condense

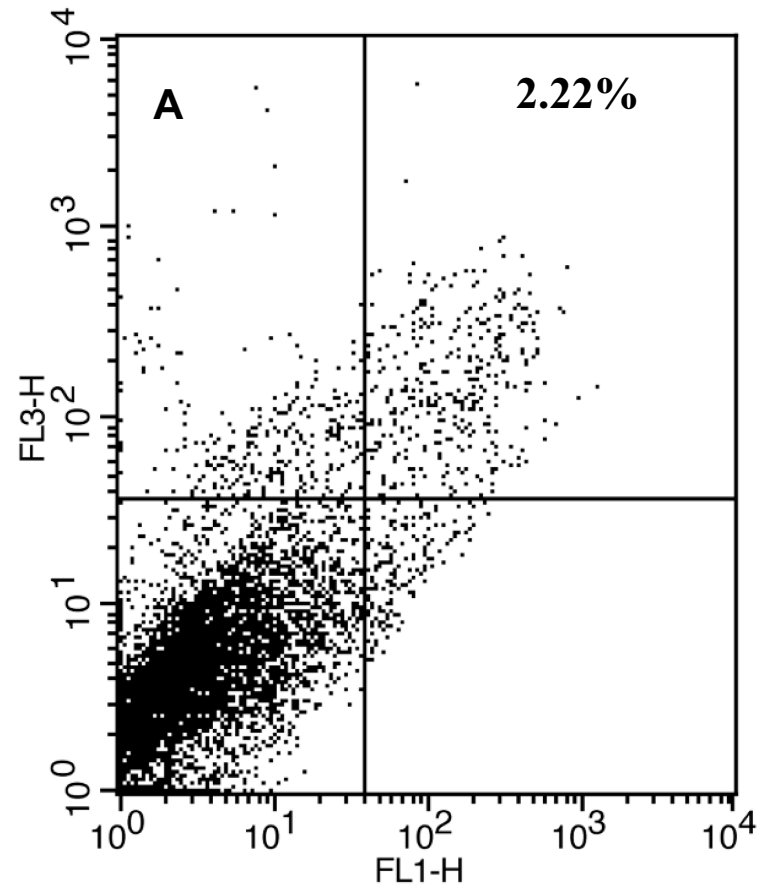

Control $\mathrm{AgNO}_{3}$ around the particles and help in screening long-distance electrostatic interactions. ${ }^{43}$ Very dilute colloidal solution of AgNPs was prepared and sonicated before to reduce the aggregation of clusters of nanoparticles. Figure 8 shows the hydrodynamic diameter of AgNPs and It was measured between 17-400 $\mathrm{nm}$. Hydrodynamic diameter is always greater than reported SEM and AFM size as it collectively represents the size of the metallic core and the biological corona that consists of functional groups originally belong to plant secondary metabolites. Size distribution by number (Inset Figure 8) represents the average size of most of the nanoparticles in the colloidal sample that was observed between $12-40 \mathrm{~nm}$ while the average hydrodynamic diameter of a single nanoparticle was reported $21.08 \mathrm{~nm}$. Polydispersity index was measured at 0.209 which signifies that the nanoparticles are moderately dispersed and well suited to be used in biomedical therapies.

\section{Cytotoxicity of Plant Aqueous Extract and AgNPs Against Colon Cancer Cells}

Colon or colorectal cancer is the third most common cancer and is a leading cause of death due to its sever action and mechanisms to resist chemotherapeutic drugs. Multiple drug resistance (MDR) to the chemotherapeutic

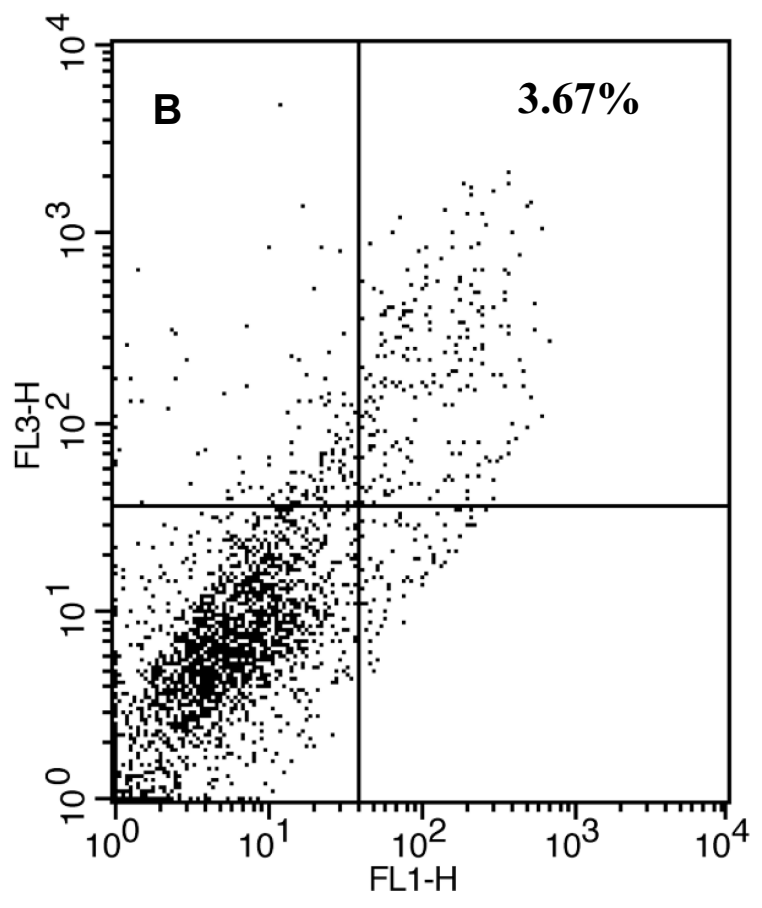

M. arvensis

Figure 10 Fluorescence-activated cell sorting (FACS) plot to represent the cytotoxicity of plant aqueous extract against $\mathrm{HCTII} 6$ colon cancer cells. (A) AgNO 3 and; (B) M. arvensis aqueous extract reported $2.22 \%$ and $3.67 \%$ cytotoxic activity, respectively. 
drugs became a global concern as it negatively affects the success rate of the disease. ${ }^{44}$

Sulforhodamine B (SRB) assay (Figure 9) results showed that the AgNPs expressed cell death and the $\mathrm{IC}_{50}$ (half-maximum inhibitory concentration) was recorded at $1.7 \mu \mathrm{g} / \mathrm{mL}$. $\mathrm{IC}_{50}$ is a quantitative measurement of the molar concentration of a material or a drug to inhibit or halt a particular biological process or its components such as enzymes, receptors or any signaling mechanism. Lower $\mathrm{IC}_{50}$ $(1.7 \mu \mathrm{g} / \mathrm{mL})$ represents the great potency of the drug and is a universal indicator to measure the efficacy of a drug.

Annexin V apoptosis assay (Figure 10) results showed that the plant aqueous extracts are not effective to induce cell death against human colon cancer cells and only $3.67 \%$ of the total number of the cells expressed cell death which shows that the plant aqueous extracts are not effective against colon cancer cells. It can be explained that the aqueous extract is not embellished with the phytochemicals to exhibit cytotoxicity against cancer cells.

The dose-responsive activity of bio-fabricated AgNPs was reported by using an Annexin $\mathrm{V}$ apoptosis assay (Figure 11) and it was found that the increase in the concentration of AgNPs dose resulted in increasing cytotoxicity against HCT116 colon cancer cells. $131 \mu \mathrm{g} / \mathrm{mL}$ of AgNPs expressed $10.05 \%$ killing of cancer cells while the toxicity increased to $30 \%$ at $262 \mu \mathrm{g} / \mathrm{mL}$. Though the exact mechanism which is responsible to evade colon cancer cells is still unknown.

The selective activity of AgNPs against colon cells can be because of the presence of chlorides in colloidal AgNPs that was observed in EDX analysis (Figure 7). Previous studies on phytochemical evaluation of $M$. arvensis confirmed the presence of Chlorine-containing sesquiterpenes and monoterpene that are mainly responsible for the presence of $\mathrm{Cl}^{41,42}$ Some studies reported the cytotoxic potential of $\mathrm{Cl}^{45-47}$ and the presence of high chlorine contents in $M$. arvensis fabricated AgNPs can be one reason for their selective anticancer activities. It was confirmed in our previous study that $M$. arvensis fabricated AgNPs are biocompatible and a very high dose of nanoparticles is required to cause lysis of Red blood cells or erythrocytes. Chloride ions contribute to exchange bicarbonates $\left(\mathrm{HCO}_{3}{ }^{-}\right)$across the plasma cell membrane of the RBCs and help to maintain ionic balance which is termed as chloride shift. It is mainly responsible for the selective cytotoxic potential of AgNPs against colon cancer cells. ${ }^{48}$ Biocompatibility of mint fabricated AgNPs against RBCs
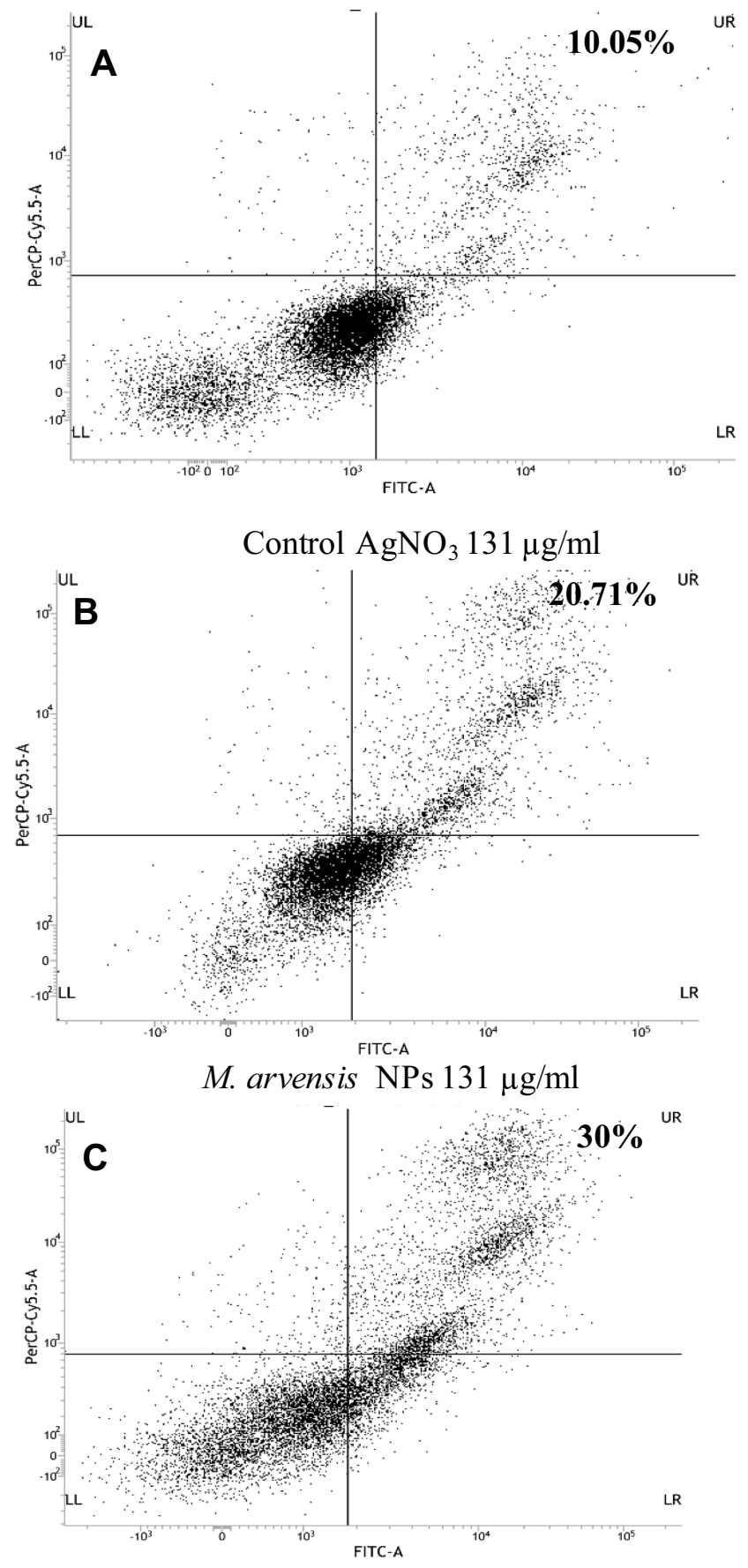

M. arvensis NPs $262 \mu \mathrm{g} / \mathrm{ml}$

Figure I I Fluorescence-activated cell sorting (FACS) plot to represent the cytotoxicity of different doses of AgNPs against HCTII6 colon cancer cells. (A) Control $\mathrm{AgNO}_{3} 131 \mu \mathrm{g} / \mathrm{mL}$; (B) AgNPs $131 \mu \mathrm{g} / \mathrm{mL}$ and (C) AgNPs $262 \mu \mathrm{g} / \mathrm{mL}$.

and their selective cytotoxic potential against colon cancer cells can help to manage the limitations of conventional treatments of colon cancer.

The other possible reason for the selective anticancer activity of AgNPs is their small size that let these NPs to internalize the cells by crossing the plasma membrane 

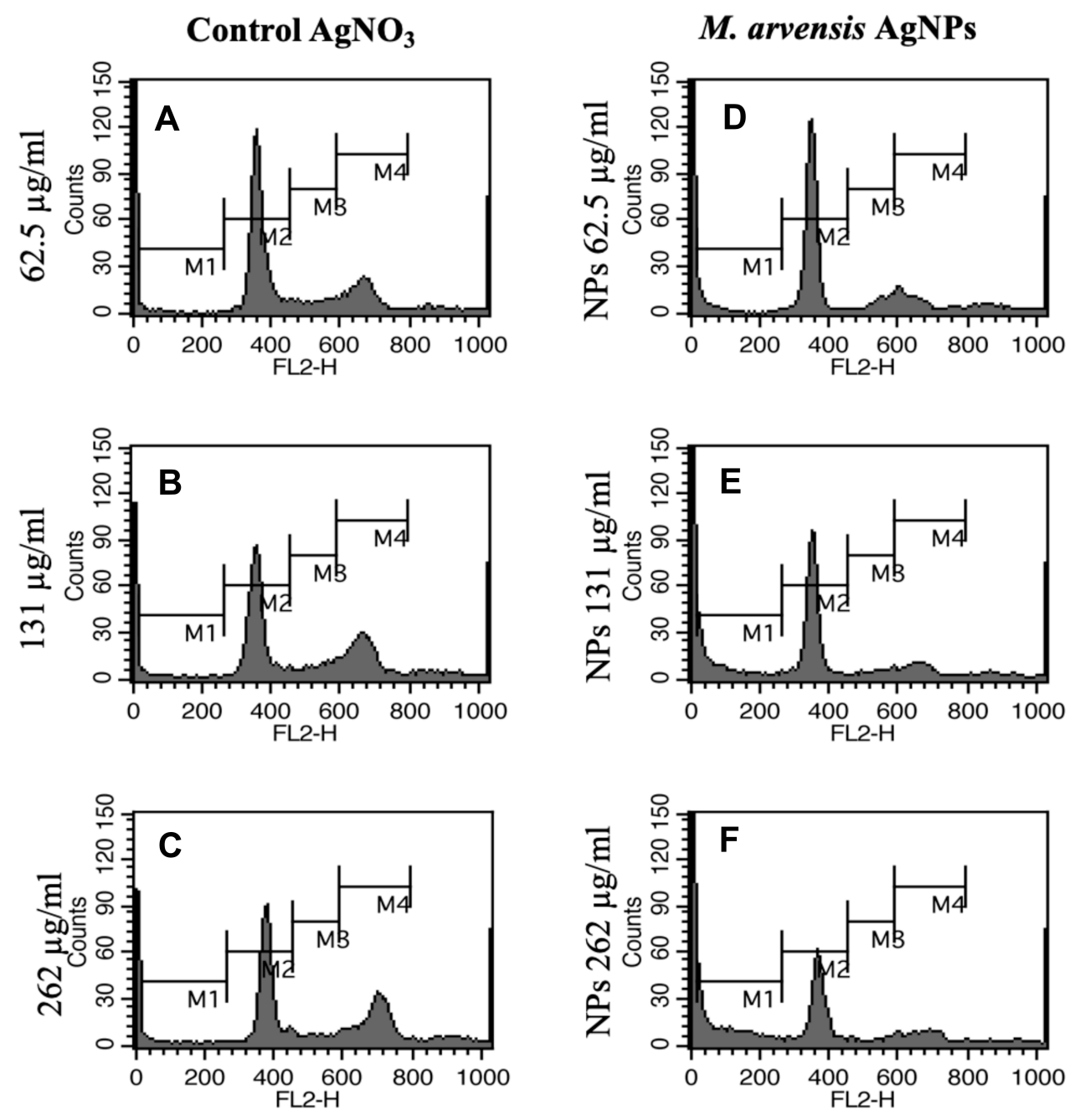

Figure 12 Effects of biosynthesized AgNP on cell cycle of colon cancer cells. (A-C) Effect of different doses of the $\mathrm{AgNO}_{3}$; (D-F) effect of different doses of AgNPs on the cell cycle of colon cancer cells.

Notes: MI, Sub-GI phase; M2, GI phase; M3, S phase; M4, G2 phase.

barrier and disruption of the cell metabolic process or the entrapment of the mitochondria to take control of the power-house of the cell. Cytotoxic potential of AgNPs against HCT116 colon cancer cells can also be attributed to the interaction of nanoparticles with DNA, RNA, and proteins which can result in altering their conformational changes and fragmentation of their active structure. Another possible reason can be the positive charge of ionic Ag that helps to get it attached with the plasma cell membrane that has negatively charged proteins which eventually break the cell membrane and lead to cell death. It is also speculated that $\mathrm{Ag}^{+}$bind with the thiol group (-SH group) of the enzymes and form the stable complexes such as Ag-S which results in the change of enzymatic configuration and blockage of activity site. , $8,39,49^{-1}$

\section{Cell Cycle Analysis of AgNPs-Treated HCTII6 Colon Cancer Cells}

Cell cycle analysis contributes greatly to determine cells in different phases of the cell cycle. Cell cycle analysis showed (Figure 12) that the bio-fabricated AgNPs have promising abelites to suspend/arrest the cell cycle. Increasing the dose of the AgNPs resulted in the entrapment of the greater number of cells in the Sub-G1 (M1) phase which shows a subsequent decrease in DNA content of cells. The peak representing the G1 (M2) decreased gradually which manifested that the less number of cells are entering the cell cycle. $26 \%$ of cells were reported separately into Sub $\mathrm{G} 1 / \mathrm{G}_{0}$ and $\mathrm{G} 1$ phase when AgNPstreated cells were used while only $4 \%$ of cells were in the $\mathrm{G} 1 / \mathrm{G}_{0}$ phase and $39 \%$ of cells were in the $\mathrm{G} 1$ phase in the respective control $\left(\mathrm{AgNO}_{3}\right)$. These results greatly suggest 
that the AgNPs bio-fabricated from M. arvensis aqueous extract are highly effective to halt the growth of colon cancer cells (HCT116) by arresting the cell cycle and most of the cells in the sample population attained death. Our results are in favor of previously reported work. ${ }^{30}$

\section{Conclusion}

Herein we explain the influence of different physicochemical conditions eg temperature, $\mathrm{pH}$, the concentration of $\mathrm{AgNO}_{3}$ and the proportion of different reactants on the synthesis of AgNPs bio-fabricated from M. arvensis (mint) aqueous extract. It was observed that the mild-acidic conditions are better for the synthesis of AgNPs at moderate temperature. Different physicochemical conditions play a vital role to carve the physical and biological attributes of the nano-moieties by altering the reaction kinetics, molecular dynamics, and catalysis. Biological applications of silver nanoparticles implicated in this study found that the NPs are highly efficacious against HCT116 human colon cancer cells. Cell cycle analysis against HCT116 cancer cells unraveled that the silver nanoparticles suspended cell division in the Sub-G1 phase which shows that the AgNPs are not only affecting the cell life but also hampering the further proliferation. The results from this study provide the experimental evidence to understand the synergistic impact of physicochemical reaction parameters on nanoparticles synthesis and their abilities to suppress the growth of cancer cells may lead to the development of highly efficacious anticancer drugs to overcome the limitations of conventional treatment of colon cancer.

\section{Acknowledgments}

We are very thankful to the Higher Education Commission of Pakistan's, International Research Support Initiative Program (IRSIP), to send B.J. to the University of Pennsylvania for experimentation. We thank Dr. Zahra Fakhraai and Aixi Zhang (Department of Chemistry, University of Pennsylvania) to support on AFM and Jamie Ford (Staff Scientist, Singh Center, University of Pennsylvania) to help with the SEM facility.

\section{Disclosure}

The authors declare no conflicts of interest.

\section{References}

1. Bapat RA, Chaubal TV, Joshi CP, et al. An overview of application of silver nanoparticles for biomaterials in dentistry. Mater Sci Eng C. 2018;91:881-898. doi:10.1016/j.msec.2018.05.069
2. Siddiqui MN, Redhwi HH, Achilias DS, Kosmidou E, Vakalopoulou E, Ioannidou MD. Green synthesis of silver nanoparticles and study of their antimicrobial properties. J Polym Environ. 2018;26(2):423-433. doi:10.1007/s10924-017-0962-0

3. Kalaiselvi D, Mohankumar A, Shanmugam G, Nivitha S, Sundararaj P. Green synthesis of silver nanoparticles using latex extract of Euphorbia tirucalli: a novel approach for the management of root knot nematode, Meloidogyne incognita. Crop Prot. 2019;117:108-114. doi:10.1016/j.cropro.2018.11.020

4. Kang T, Kim YG, Kim D, Hyeon T. Inorganic nanoparticles with enzyme-mimetic activities for biomedical applications. Coord Chem Rev. 2020;403:213092. doi:10.1016/j.ccr.2019.213092

5. Kumar S, Nehra M, Kedia D, Dilbaghi N, Tankeshwar K, Kim K-H. Nanotechnology-based biomaterials for orthopaedic applications: recent advances and future prospects. Mater Sci Eng C. 2020;106:110154. doi:10.1016/j.msec.2019.110154

6. Kalimuthu K, Cha BS, Kim S, Park KS. Eco-friendly synthesis and biomedical applications of gold nanoparticles: a review. Microchem J. 2020;152:104296. doi:10.1016/j.microc.2019.104296

7. Manosalva N, Tortella G, Cristina Diez M, et al. Green synthesis of silver nanoparticles: effect of synthesis reaction parameters on antimicrobial activity. World J Microbiol Biotechnol. 2019;35(6). doi:10.1007/s11274-019-2664-3

8. Wei L, Lu J, Xu H, Patel A, Chen ZS, Chen G. Silver nanoparticles: synthesis, properties, and therapeutic applications. Drug Discov Today. 2015;20(5):595-601. doi:10.1016/j.drudis.2014.11.014

9. Kim DY, Saratale RG, Shinde S, Syed A, Ameen F, Ghodake G. Green synthesis of silver nanoparticles using Laminaria japonica extract: characterization and seedling growth assessment. $J$ Clean Prod. 2016;172:2910-2918. doi:10.1016/j.jclepro.2017.11.123

10. de Oliveira ACJ, de Araújo AR, Quelemes PV, et al. Solvent-free production of phthalated cashew gum for green synthesis of antimicrobial silver nanoparticles. Carbohydr Polym. 2019;213:176-183. doi:10.1016/j.carbpol.2019.02.033

11. Khan T, Ullah N, Khan MA, Mashwani Z-R, Nadhman A. Plant-based gold nanoparticles; a comprehensive review of the decade-long research on synthesis, mechanistic aspects and diverse applications. Adv Colloid Interface Sci. 2019;102017. doi:10.1016/j.cis.2019.102017.

12. Ulaeto SB, Mathew GM, Pancrecious JK, et al. Biogenic $\mathrm{Ag}$ nanoparticles from neem extract: their structural evaluation and antimicrobial effects against pseudomonas nitroreducens and aspergillus unguis (NII 08123). ACS Biomater Sci Eng. 2019;6:235-245. doi:10.1021/acsbiomaterials.9b01257

13. Farokhzad OC, Langer R. Nanomedicine: developing smarter therapeutic and diagnostic modalities. Adv Drug Deliv Rev. 2006;58 (14):1456-1459. doi:10.1016/j.addr.2006.09.011

14. Langer R. Biomaterials in drug delivery and tissue engineering: one laboratory's experience. Acc Chem Res. 2000;33(2):94-101. doi:10.1021/ar9800993

15. Zhang L, Gu FX, Chan JM, Wang AZ, Langer RS, Farokhzad OC. Nanoparticles in medicine: therapeutic applications and developments. Clin Pharmacol Ther. 2008;83(5):761-769. doi:10.10 38/sj.clpt.6100400

16. Langer R, Peppas NA. Advances in biomaterials, drug delivery, and bionanotechnology. AIChE J. 2003;49.:2990-3006. doi:10.1002/ aic. 690491202

17. Alexis F, Pridgen E, Molnar LK, Farokhzad OC. Factors affecting the clearance and biodistribution of polymeric nanoparticles. Mol Pharm. 2008;5.:505-515. doi:10.1021/mp800051m

18. Farokhzad OC, Langer R. Impact of nanotechnology on drug delivery. ACS Nano. 2009;3(1):16-20. doi:10.1021/nn900002m

19. Petri-Fink A, Chastellain M, Juillerat-Jeanneret L, Ferrari A, Hofmann H. Development of functionalized superparamagnetic iron oxide nanoparticles for interaction with human cancer cells. Biomaterials. 2005;26(15):2685-2694. doi:10.1016/j.biomaterials. 2004.07.023 
20. Akhtar MS, Panwar J, Yun YS. Biogenic synthesis of metallic nanoparticles by plant extracts. ACS Sustain Chem Eng. 2013;1 (6):591-602. doi:10.1021/sc300118u

21. Mashwani ZUR, Khan T, Khan MA, Nadhman A. Synthesis in plants and plant extracts of silver nanoparticles with potent antimicrobial properties: current status and future prospects. Appl Microbiol Biotechnol. 2015;99(23):9923-9934. doi:10.1007/s00253-015-6987-1

22. Anandan M, Poorani G, Boomi P, et al. Green synthesis of anisotropic silver nanoparticles from the aqueous leaf extract of Dodonaea viscosa with their antibacterial and anticancer activities. Process Biochem. 2019;80:80-88. doi:10.1016/j.procbio.2019.02.014

23. Veisi H, Azizi S, Mohammadi P. Green synthesis of the silver nanoparticles mediated by Thymbra spicata extract and its application as a heterogeneous and recyclable nanocatalyst for catalytic reduction of a variety of dyes in water. J Clean Prod. 2018;170:1536-1543. doi:10.1016/j.jclepro.2017.09.265

24. Ali M, Kim B, Belfield KD, Norman D, Brennan M, Ali GS. Green synthesis and characterization of silver nanoparticles using Artemisia absinthium aqueous extract - A comprehensive study. Mater Sci Eng C. 2016;58:359-365. doi:10.1016/j.msec.2015.08.045

25. Sharma V, Kaushik S, Pandit P, Dhull D, Yadav JP, Kaushik S. Green synthesis of silver nanoparticles from medicinal plants and evaluation of their antiviral potential against chikungunya virus. Appl Microbiol Biotechnol. 2019;103(2):881-891. doi:10.1007/s00253-018-9488-1

26. Celebioglu A, Topuz F, Yildiz ZI, Uyar T. One-step green synthesis of antibacterial silver nanoparticles embedded in electrospun cyclodextrin nanofibers. Carbohydr Polym. 2019;207:471-479. doi:10.1016/j.carbpol.2018.12.008

27. Meva FE, Mbeng JOA, Ebongue CO, et al. Stachytarpheta cayennensis aqueous extract, a new bioreactor towards silver nanoparticles for biomedical applications. J Biomater Nanobiotechnol. 2019;10 (02):102-119. doi:10.4236/jbnb.2019.102006

28. Coradeghini R, Gioria S, García CP, et al. Size-dependent toxicity and cell interaction mechanisms of gold nanoparticles on mouse fibroblasts. Toxicol Lett. 2013;217(3):205-216. doi:10.1016/j. toxlet.2012.11.022

29. Vichai V, Kirtikara K. Sulforhodamine B colorimetric assay for cytotoxicity screening. Nat Protoc. 2006;1(3):1112-1116. doi:10.1038/nprot.2006.179

30. Fani S, Kamalidehghan B, Lo KM, et al. Anticancer activity of a monobenzyltin complex $\mathrm{C} 1$ against MDA-MB-231 cells through induction of Apoptosis and inhibition of breast cancer stem cells. Sci Rep. 2016;6. doi:10.1038/srep38992

31. De Matteis V, Malvindi MA, Galeone A, et al. Negligible particle-specific toxicity mechanism of silver nanoparticles: the role of $\mathrm{Ag}+$ ion release in the cytosol. Nanomed Nanotechnol Biol Med. 2015;11(3):731-739. doi:10.1016/j.nano.2014.11.002

32. Abdelghany TM, Al-Rajhi AMH, Al Abboud MA, et al. Recent advances in green synthesis of silver nanoparticles and their applications: about future directions. A review. Bionanoscience. 2018;8 (1):5-16. doi:10.1007/s12668-017-0413-3

33. Singh R, Shedbalkar UU, Wadhwani SA, Chopade BA. Bacteriagenic silver nanoparticles: synthesis, mechanism, and applications. Appl Microbiol Biotechnol. 2015;99(11):4579-4593. doi:10.1007/s00253015-6622-1

34. Mathew A, Thomas S. Green synthesis, characterization and applications of silver nanoparticles using thunbergia grandiflora Roxb. J Nanosci Technol. 2019;5(2):669-672. doi:10.30799/jnst.217.19050206
35. Chandrasekaran R, Yadav SA, Sivaperumal S. Phytosynthesis and characterization of copper oxide nanoparticles using the aqueous extract of beta vulgaris $\mathrm{L}$ and evaluation of their antibacterial and anticancer activities. J Clust Sci. 2019;31(1):221-230. doi:10.1007/ s10876-019-01640-6

36. Nindawat S, Agrawal V. Fabrication of silver nanoparticles using Arnebia hispidissima (Lehm.) A. DC. root extract and unravelling their potential biomedical applications. Artif Cells Nanomed Biotechnol. 2019;47(1):166-180. doi:10.1080/21691401.2018.1548469

37. Zaleska-Medynska A, Marchelek M, Diak M, Grabowska E. Noble metal-based bimetallic nanoparticles: the effect of the structure on the optical, catalytic and photocatalytic properties. Adv Colloid Interface Sci. 2016;229:80-107. doi:10.1016/j.cis.2015.12.008

38. Jadhav K, Deore S, Dhamecha D, et al. Phytosynthesis of silver nanoparticles: characterization, biocompatibility studies, and anticancer activity. ACS Biomater Sci Eng. 2018;4(3):892-899. doi:10.1021/acsbiomaterials.7b00707

39. Durán N, Durán M, de Jesus MB, Seabra AB, Fávaro WJ, Nakazato G. Silver nanoparticles: a new view on mechanistic aspects on antimicrobial activity. Nanomed Nanotechnol Biol Med. 2016;12 (3):789-799. doi:10.1016/j.nano.2015.11.016

40. Pareek V, Gupta R, Panwar J. Do physico-chemical properties of silver nanoparticles decide their interaction with biological media and bactericidal action? A review. Mater Sci Eng C. 2018;90:739-749. doi:10.1016/j.msec.2018.04.093

41. Dembitsky VM. Chlorine-containing sesquiterpenes of higher plants. Chem Sustain Dev. 2002;10:363-370.

42. Shaiq Ali M, Saleem M, Ahmad W, Parvez M, Yamdagni R. A chlorinated monoterpene ketone, acylated $\beta$-sitosterol glycosides and a flavanone glycoside from Mentha longifolia (Lamiaceae). Phytochemistry. 2002;59(8):889-895. doi:10.1016/S0031-9422(01) 00490-3

43. Farrell E, Brousseau J. Guide for DLS sample preparation. Brookhaven Instrum. 2014;1(631):1-3.

44. Chandran SP, Natarajan SB, Chandraseharan S, Mohd Shahimi MSB. Nano drug delivery strategy of 5-fluorouracil for the treatment of colorectal cancer. J Cancer Res Pract. 2017;4(2):45-48. doi:10.1016/ j.jcrpr.2017.02.002

45. Gottardi W, Nagl M. Chlorine covers on living bacteria: the initial step in antimicrobial action of active chlorine compounds. $J$ Antimicrob Chemother. 2005;55(4):475-482. doi:10.1093/jac/ dki054

46. Kim J, Pitts B, Stewart PS, Camper A, Yoon J. Comparison of the antimicrobial effects of chlorine, silver ion, and tobramycin on biofilm. Antimicrob Agents Chemother. 2008;52(4):1446-1453. doi:10.1128/AAC.00054-07

47. Odlaug TE. Antimicrobial Activity of Halogens. J Food Prot. 1981;44(8):608-613. doi:10.4315/0362-028x-44.8.608

48. Javed B, Raja NI, Nadhman A, Mashwani ZUR. Understanding the potential of bio - fabricated non - oxidative silver nanoparticles to eradicate Leishmania and plant bacterial pathogens. Appl Nanosci. 2020;0123456789. doi:10.1007/s13204-020-01355-5

49. Shi J, Kantoff PW, Wooster R, Farokhzad OC. Cancer nanomedicine: progress, challenges and opportunities. Nat Rev Cancer. 2017;17 (1):20-37. doi:10.1038/nrc.2016.108 


\section{Publish your work in this journal}

The International Journal of Nanomedicine is an international, peerreviewed journal focusing on the application of nanotechnology in diagnostics, therapeutics, and drug delivery systems throughout the biomedical field. This journal is indexed on PubMed Central, MedLine, CAS, SciSearch ${ }^{\circledR}$, Current Contents ${ }^{\circledR} /$ Clinical Medicine,
Journal Citation Reports/Science Edition, EMBase, Scopus and the Elsevier Bibliographic databases. The manuscript management system is completely online and includes a very quick and fair peer-review system, which is all easy to use. Visit http://www.dovepress.com/ testimonials.php to read real quotes from published authors. 